\title{
Comparison of the meta Pathway Operons on NAH Plasmid pWW60-22 and TOL Plasmid pWW53-4 and Its Evolutionary Significance
}

\author{
By SUSAN J. ASSINDER AND PETER A. WILLIAMS* \\ Department of Biochemistry, School of Biological Sciences, University College of North Wales, \\ Bangor, Gwynedd LL57 2UW, UK
}

(Received 14 March 1988; revised 27 June 1988)

\begin{abstract}
The regulated meta pathway operon for the catabolism of salicylate on the naphthalene plasmid pWW60-22 was cloned into the broad-host-range vector pKT230 on a $17.5 \mathrm{kbp} \mathrm{BamHI}$ fragment. The recombinant plasmid conferred the ability to grow on salicylate when mobilized into plasmid-free Pseudomonas putida PaW130. A detailed restriction map of the insert was derived and the locations of some of the genes were determined by subcloning and assaying for their gene products in Escherichia coli and P. putida hosts. The existence of a regulatory gene was demonstrated by the induction of enzyme activities in the presence of salicylate. DNA-DNA hybridization indicated a high degree of structural homology between the $\mathrm{pWW60-22}$ operon and the analogous meta pathway operon on TOL plasmid pWW53-4. The data are consistent with the structural genes being arranged in an identical linear array and suggest an evolutionary link between the two catabolic systems.
\end{abstract}

\section{INTRODUCTION}

The involvement of plasmids in the catabolism of naphthalene by Pseudomonas strains has been well documented (Dunn \& Gunsalus, 1973; Boronin et al., 1977, 1980). In Pseudomonas strain NCIB 9816, the genes coding for the breakdown of naphthalene are carried on an $87 \mathrm{kbp}$ IncP9 plasmid, pWW60 (Cane \& Williams, 1982). The ability to degrade naphthalene has been transferred by conjugation into a plasmid-free Pseudomonas putida strain, PaW340, to give the transconjugant $\mathrm{PaW} 701$. The plasmid in $\mathrm{PaW} 701$, pWW60-1, is responsible for the conversion of naphthalene as far as catechol, which is then metabolized by the enzymes of the chromosomally encoded ortho pathway. This has the consequence that growth on 2methylnaphthalene is not supported since the ortho pathway has an absolute specificity for catechol and cannot utilize its methylated derivatives (Feist \& Hegeman, 1969). However, spontaneous mutants of $\mathrm{PaW} 701$, selected through their ability to grow on 2-methylnaphthalene, use a plasmid-coded meta pathway for the metabolism of catechol. These mutants have undergone a small deletion $(1.2-1.6 \mathrm{kbp})$ in the plasmid between the genes encoding salicylate hydroxylase $(\mathrm{SH})$ and catechol 2,3-oxygenase $(\mathrm{C} 23 \mathrm{O})$ facilitating the expression of previously silent meta pathway genes; pWW60-22, the plasmid used in the present study, is the deleted plasmid in one such mutant.

Restriction endonuclease mapping and transposon mutagenesis of pWW60-1 have shown the early enzymes of the naphthalene catabolic pathway (naphthalene to salicylate) and the meta pathway genes (salicylate to pyruvate) to be clustered in two distinct and spatially separated operons (Cane \& Williams, 1986). A similar situation exists in the TOL plasmid pWW53-4, which encodes a set of inducible enzymes required for the oxidative degradation of toluene via

\footnotetext{
Abbreviations: SH, salicylate hydroxylase; C23O, catechol 2,3-oxygenase; HMSD, 2-hydroxymuconic semialdehyde dehydrogenase; HMSH, 2-hydroxymuconic semialdehyde hydrolase; 4OT, 4-oxalocrotonate tautomerase; 4OD, 4-oxalocrotonate decarboxylase; OPH, 2-oxopent-4-enoate hydratase; HOA, 4-hydroxy-2oxovalerate aldolase.
} 
meta-cleavage of catechol (Keil et al., 1985b). The genes responsible for this oxidation comprise an upper pathway operon (toluene to benzoate) and a separate meta-cleavage pathway operon (benzoate to pyruvate), controlled respectively by the products of the regulatory genes $x y l R$ and $x y l S$ (Keil et al., 1987).

The present study aimed to elucidate further the genetic organization of the naphthalene meta pathway operon on $\mathrm{pWW60-22}$ and to compare it to the analogous pathway on TOL plasmid pWW 53-4 in an attempt to understand the evolutionary relationships between the two systems.

\section{METHODS}

Bacterial strains and plasmids. The Escherichia coli and Pseudomonas putida strains and the plasmids used during this study are detailed in Table 1.

Media and culture conditions. P. putida strains were grown on solid and liquid minimal medium (Worsey \& Williams, 1975) with added streptomycin $\left(150 \mu \mathrm{g} \mathrm{ml}^{-1}\right)$ to ensure maintenance of recombinant plasmids. The media and methods used for the cultivation of $E$. coli have been described previously (Keil et al., 1985a).

Enzyme assays. Cell-free extracts were prepared according to Cane \& Williams (1982) but the period of sonication was reduced to two $30 \mathrm{~s}$ bursts. The enzyme assay procedures for catechol 2,3-oxygenase (C23O), 2hydroxymuconic semialdehyde hydrolase (HMSH), 2-hydroxymuconic semialdehyde dehydrogenase (HMSD) and 4-hydroxy-2-oxovalerate aldolase (HOA) were taken from Sala-Trepat \& Evans (1971). The modified assay of Harayama et al. (1984) was employed for 4-oxalocrotonate decarboxylase (4OD). For 4-oxalocrotonate tautomerase (4OT), reaction mixtures were as for Sala-Trepat \& Evans (1971) but the procedure was modified such that the $A_{295}$ was followed until it had fallen from $2 \cdot 0$ to $0 \cdot 8$. A tangent was then drawn to the curve at an absorbance of 1.0 and the slope of the tangent taken as the rate of tautomerization. Non-enzymic tautomerization was measured in an identical manner and subtracted from the rate obtained in the presence of cell-free extract. 2Oxopent-4-enoate hydratase (OPH) was assayed according to Collinsworth et al. (1973). Substrates for enzyme assays were as described previously (Keil et al., 1987). Protein concentrations were determined by the biuret procedure.

Plasmid extraction and DNA manipulation. Plasmid pWW60-22 was extracted by the method of Wheatcroft \& Williams (1981). E. coli and $P$. putida strains were screened for the presence of small recombinant plasmids according to Holmes \& Quigley (1981) and vector and cloned DNA prepared in quantity by CsCl density-gradient centrifugation of cleared lysates (Guerry et al., 1973). Restriction endonuclease digestion and ligation with T4 ligase were done in accordance with the manufacturer's instructions. $E$. coli strains were transformed by standard procedures (Cohen et al., 1972) and transformants selected on media containing antibiotics appropriate to the vector. Colonies carrying recombinant plasmids expressing $\mathrm{C} 23 \mathrm{O}$ activity were detected by the catechol spray test (Franklin et al., 1981).

Mobilization of recombinant plasmids. All pKT230-derived recombinant plasmids were mobilized into plasmidfree $P$. putida strain PaW130 using the unstable RP4 derivative pNJ5000 (Grinter, 1983) as described by Keil et al. $(1985 b)$.

Table 1. Bacterial strains and plasmids

\begin{tabular}{|c|c|c|}
\hline Strain & Plasmid & Notes and references \\
\hline \multicolumn{3}{|l|}{ E. coli } \\
\hline ED8654 & - & Murray et al. (1977) \\
\hline JM103 & - & Messing et al. (1981) \\
\hline \multicolumn{3}{|l|}{ P. putida } \\
\hline PaW11 & - & Cane \& Williams (1982) \\
\hline PaW130 & - & Keil et al. $(1985 b)$ \\
\hline PaW701 & pWW60-1 & $\begin{array}{l}\mathrm{Nah}^{+} 2 \mathrm{MeNah}^{-} \mathrm{Sal}^{+} 4 \mathrm{MeSal}^{-} \\
\text {Cane \& Williams (1982) }\end{array}$ \\
\hline \multirow[t]{3}{*}{ PaW719 } & pWW60-22 & $\begin{array}{l}\mathrm{Nah}^{+} 2 \mathrm{MeNah}^{+} \mathrm{Sal}^{+} 4 \mathrm{MeSal}^{+} \\
\text {Cane \& Williams (1982) }\end{array}$ \\
\hline & $\begin{array}{l}\text { pWW53-4 } \\
\text { pWW53-3506 } \\
\text { pWW53-3508 } \\
\text { pWW53-3510 }\end{array}$ & $\begin{array}{l}\text { Keil et al. }(1985 b) \\
\text { Keil et al. }(1987) \\
\text { Keil et al. }(1987) \\
\text { Keil et al. }(1985 b)\end{array}$ \\
\hline & $\begin{array}{l}\text { pKT230 } \\
\text { pUC18 } \\
\text { pBR322 } \\
\text { pNJ5000 }\end{array}$ & $\begin{array}{l}\mathrm{Km}^{\mathrm{R}} \mathrm{Sm}^{\mathrm{R}}: \text { Bagdasarian et al. }(1981) \\
\text { Yanisch-Perron et al. }(1985) \\
\text { Bolivar et al. }(1977) \\
\text { Grinter (1983) }\end{array}$ \\
\hline
\end{tabular}


DNA-DNA hybridization. Restriction fragments were separated by agarose gel electrophoresis and transferred by Southern blotting (Southern, 1975) to Biodyne filter membranes (Pall Ultrafine Filtration Corp.). Cloned fragments to be used as radio-labelled probes were separated from vector DNA by agarose gel electrophoresis and extracted according to Girvitz et al. (1980).

The procedures for nick-translation and hybridization have been described previously (Keil \& Williams, 1985).

\section{RESULTS}

\section{Molecular cloning of BamHI fragment $B C^{\prime \prime}$ from $p W W 60-22$}

Plasmid pWW60-22 is derived from pWW60-1 by spontaneous deletion of $1.6 \mathrm{kbp}$ of DNA between the $\mathrm{C} 23 \mathrm{O}$ and $\mathrm{SH}$ genes located on BamHI fragment BC (Cane \& Williams, 1982). The resultant novel BamHI fragment in pWW60-22 is designated BC". Purified pWW60-22 DNA was ligated into the broad-host-range vector pKT230 after restriction with BamHI. E. coli transformants were sprayed with $100 \mathrm{mM}$-catechol to detect those capable of converting catechol to the yellow compound 2-hydroxymuconic semialdehyde. One such transformant was selected which contained a recombinant plasmid (designated pWW60-3026) carrying the $17.5 \mathrm{kbp}$ BamHI fragment BC". Mobilization of pWW60-3026 into plasmid-free $P$. putida strain PaW130 conferred on it the ability to grow on salicylate, 4-methylsalicylate and 5-methylsalicylate as sole

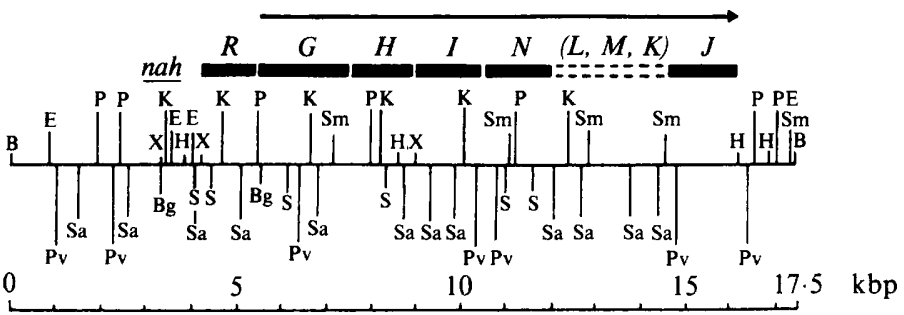

Plasmid

pWW60-3037

pWW60-3026

pWW60-3046

pWW60-3032

pWW60-3031

pWW60-3030

pWW60-3027

pWW60-3038

pWW60-3043

pWW60-3041

pWW60-3049

pWW60-3050

pWW60-3051

pWW60-3052

pWW60-3053

pWW60-3042

pWW60-3040

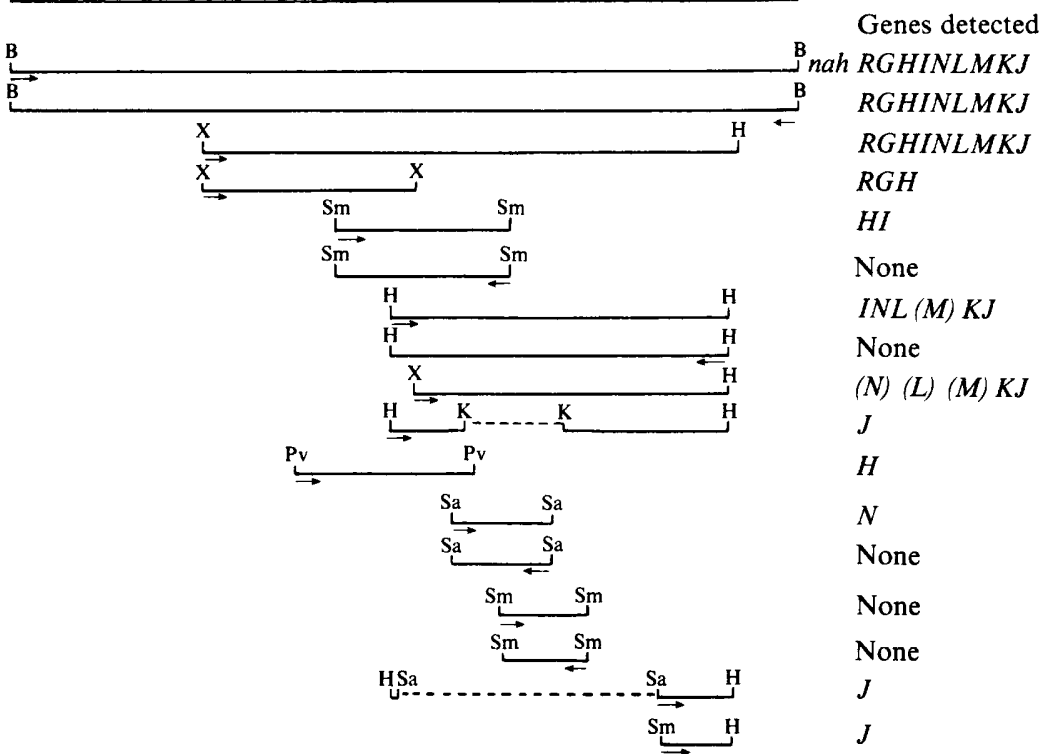

Fig. 1. Restriction map of BamHI fragment $B C^{\prime \prime}$ from naphthalene plasmid pWW60-22 and its derivative subclones. The small arrows indicate the direction of transcription from the vector promoters. The abbreviations for the restriction enzymes are as follows: $\mathrm{B}, \mathrm{BamHI} ; \mathrm{Bg}, \mathrm{Bg} / \mathrm{II}$; E, EcoRI; H, HindIII; K, KpnI; Pv, PvuII; P, PstI ; S, SstI; Sa, SalI ; Sm, SmaI ; X, XhoI. The locations assigned to the genes of the meta pathway operon are shown above the map, and the genes detected on each of the subclones are listed. Where genes are in parentheses their presence has not been proven experimentally for the particular subclone, but deduced by comparison with other recombinant plasmids. 
Table 2. Recombinant plasmids carrying cloned nah genes

Plasmid*

pWW60-3037

pWW60-3026

pWW60-3046

pWW60-3044

pWW60-3032

pWW60-3031

pWW60-3030

pWW60-3027

pWW60-3038

pWW60-3043

pWW60-3041

pWW60-3049

pWW60-3050

pWW60-3051

pWW60-3052

pWW60-3053

pWW60-3042

pWW60-3040

pWW60-3036
Notes

BamHI fragment $\mathrm{BC}^{\prime \prime}$ of pWW60-22 in pKT230

$\mathrm{BC}^{\prime \prime}$ in reverse orientation in pKT230

Xhol fragment XC" of pWW60-3032 cloned into pWW60-3043

HindIII fragment HS of pWW60-1 in pBR322

$X h o$ I fragment $\mathrm{XC}^{\prime \prime}$ of pWW60-3037 in pKT230

$3.7 \mathrm{kbp}$ SmaI fragment of pWW60-3037 in pKT230

$3.7 \mathrm{kbp} S m a$ I fragment in reverse orientation in pKT230

HindIII fragment HD of pWW60-3037 in pKT230

$\mathrm{HD}$ in reverse orientation in pKT230

$7 \cdot 2 \mathrm{kbp}$ XhoI-HindIII fragment of pWW60-3027 obtained by $X$ hol digestion and religation Internal $2.4 \mathrm{kbp} K p n I$ fragment of pWW60-3027 deleted from pWW60-3027 by KpnI digestion and religation

4.0 kbp PvuII fragment of pWW60-3037 obtained by PvuII digestion and ligation into SmaI site of pKT230

$2 \cdot 1 \mathrm{kbp}$ SalI fragment of pWW60-3027 obtained by SalI digestion and ligation into pUC18

$2.1 \mathrm{kbp} S a l \mathrm{l}$ fragment in reverse orientation in pUC18

$1.8 \mathrm{kbp}$ Smal fragment of pWW60-3027 in pK T230

$1.8 \mathrm{kbp} S m a \mathrm{I}$ fragment in reverse orientation in pKT230

$1.8 \mathrm{kbp}$ SalI-HindIII fragment of pWW60-3027 obtained by SalI digestion and religation

$1.7 \mathrm{kbp}$ SmaI-HindIII fragment of pWW60-3027 obtained by SmaI digestion and religation

HindIII fragment $\mathrm{HU}$ of pWW60-3037 in pKT230

* Recombinant plasmids were maintained in E. coli ED8654 or P. putida PaW130 with the exception of pWW60-3050 and pWW60-3051, which were isolated in E. coli JM103.

carbon sources. The recombinant plasmid also conferred growth on salicylate and its methylated derivatives to a plasmid-free mutant $\mathrm{PaW} 11$ which has a non-functional ortho pathway (Cane \& Williams, 1982).

A detailed physical map of $\mathrm{BC}^{\prime \prime}$ for 11 restriction enzymes was derived and a number of subclones constructed (Fig. 1, Table 2).

\section{Sequential hybridization experiments using TOL plasmid meta pathway genes}

DNA homology was demonstrated previously (Cane \& Williams, 1986) between the C23O gene $(n a h H)$ on plasmid pWW60-22 and the equivalent gene $(x y l E)$ on the archetypal TOL plasmid $\mathrm{pWW}$. To extend this analysis, a sequential series of DNA probes was derived from the HindIII fragment HA of pWW53-4 which encodes a functional meta pathway operon (Keil et al., 1985b). Table 3 lists the NAH meta pathway genes and their analogues on the TOL operon. The majority of the $\mathrm{pWW} 53-4$ probes hybridized strongly to $\mathrm{BC}^{\prime \prime}$, indicating a considerable degree of DNA homology (Fig. 2). The pattern of hybridization observed was consistent with the genes being located in the same linear array within the two operons. The meta pathway operon on $\mathrm{BC}^{\prime \prime}$ was seen to extend from the $\mathrm{C} 23 \mathrm{O}$ gene commencing around coordinate 7.4 to co-ordinate 16.2 at the end of HindIII fragment HD. No hybridization was observed when plasmid pWW60-3036, carrying the adjacent $0.9 \mathrm{kbp}$ HindIII fragment (HU) as its insert, was used as a probe against HA of pWW53-4 (probe 7; Fig. 2). Probes derived from the pWW53-4 regulatory gene $x y l R$ (probe 8, Fig. 2) and from the regulatory gene $x y l S$ of TOL plasmid pWW0 (Spooner et al., 1986; not shown on Fig. 2) also failed to show any homology to $\mathrm{BC}^{\prime \prime}$

The TOL genes $x y l D$ and $x y l L$ encode enzymes responsible for the breakdown of benzoate to catechol. A large DNA probe from pWW 53-4 HA carrying $x y l D$ and $x y l L$ (not shown on Fig. 2) failed to hybridize to $\mathrm{BC}^{\prime \prime}$. However, it did hybridize weakly to BC of pWW60-1 and the region of homology was shown to be limited to the HindIII fragment HS which is deleted when pWW60-22 is formed from pWW60-1 (Cane \& Williams, 1982). When fragment HS of pWW601 was subcloned (pWW60-3044) and used as a probe against multiple digests of pWW53-4 HA, hybridization was localized to a $0.8 \mathrm{kbp}$ region at the upstream end of the fragment (probe 1, Fig. 2). 


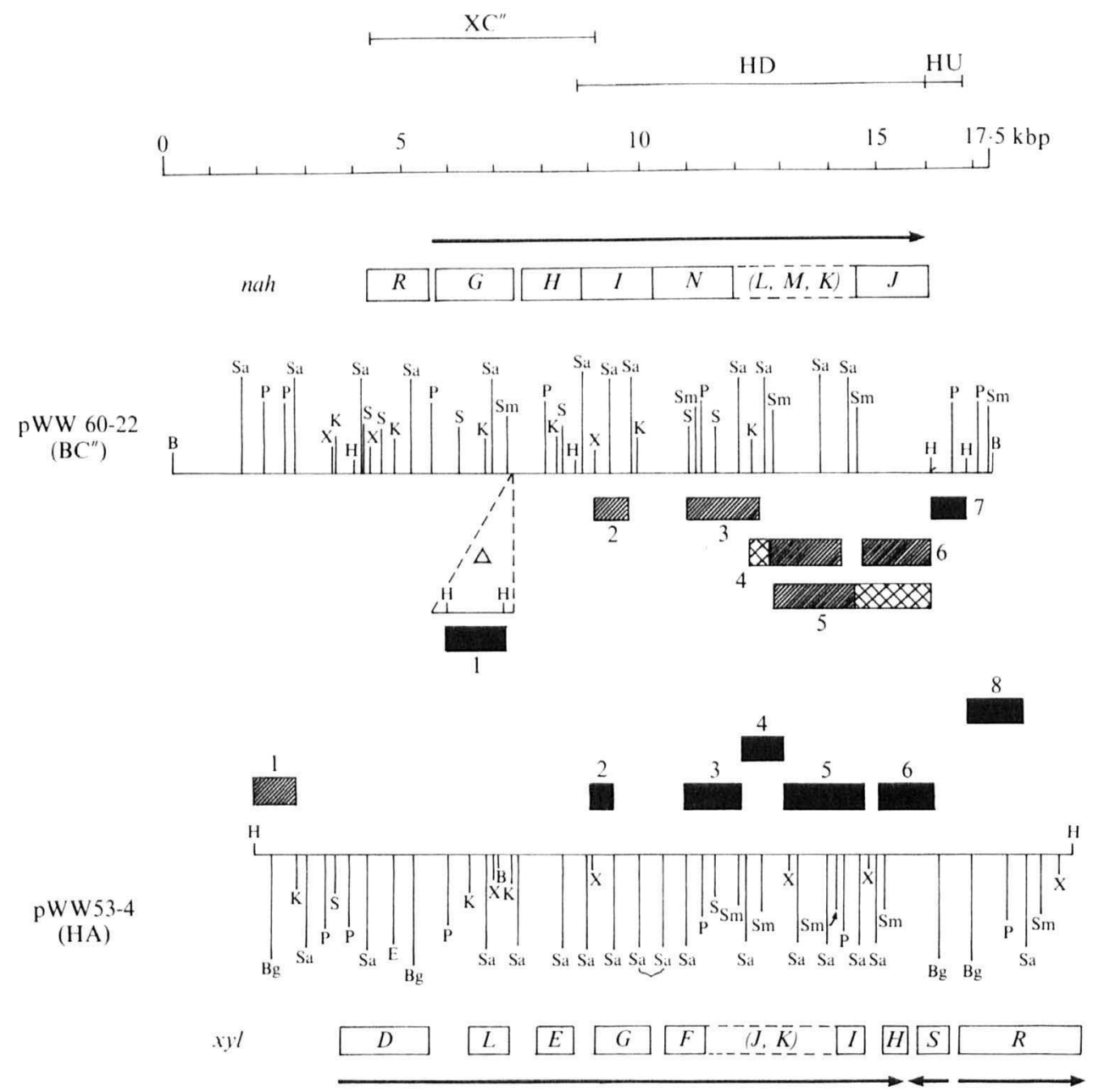

Fig. 2. Colinearity of hybridization between meta pathway genes of pWW53-4 and pWW60-22. The restriction map and positions of the pWW53-4 genes are taken from Keil et al. (1987): two alternative locations for a single Sall site which have not been distinguished are bracketed. The solid black boxes represent probe DNA and the regions of DNA to which they hybridized strongly are hatched. Regions of weak hybridization found for some of the probes are cross-hatched. DNA probes are as follows: 1 , $1.0 \mathrm{kbp}$ HindIII fragment HS from pWW60-1 (Cane \& Williams, 1982);2, 0.5 kbp XhoI-SalI fragment from pWW53-3510 (Keil et al., 1985b); 3, 1.1 kbp SalI fragment from pWW53-3510; 4, 0.8 kbp SalIXhol fragment from pWW53-3510; 5, 1.6 kbp Xhol fragment from pWW53-3506 (Keil et al., 1987); 6, $1.3 \mathrm{kbp} \mathrm{SmaI-Bg/II}$ fragment from pWW53-3508 (Keil et al., 1987); 7, 0.7 kbp HindIII fragment HU from pWW60-3036 (this study); 8, 1.6 kbp BglII-SmaI fragment from pWW53-3508. All probes were prepared by restriction enzyme digestion of the appropriate plasmid followed by electroelution of the desired DNA band from agarose gels.

\section{Localization of naphthalene meta pathway genes}

The enzyme activities in $E$. coli and $P$. putida strains carrying recombinant plasmids are detailed in Table 4. Cells carrying pWW60-3037, which contains BC", expressed all of the enzymes of the meta pathway operon, albeit at very low levels for HMSH (nahN). Similar specific activities were demonstrated in both $E$. coli and $P$. putida carrying plasmid pWW603026 , which constitutes $\mathrm{BC}^{\prime \prime}$ cloned in the opposite orientation relative to the $\mathrm{Km}^{\mathrm{R}}$ promoter of pKT230 compared with pWW60-3037. The specific activities of C23O, HMSD (nahl) and OPH (nahL) were similar regardless of whether the host strain was E. coli or P. putida. For 4OT (nahJ) and OPH (nahL), the activities were two- to three-fold higher in $P$. putida hosts. HMSH levels 
Table 3. Gene designations for the meta pathway enzymes of NAH and TOL plasmids

Enzyme

Catechol 2,3-oxygenase (C23O)

2-Hydroxymuconic semialdehyde hydrolase (HMSH)

2-Hydroxymuconic semialdehyde dehydrogenase (HMSD)

4-Oxalocrotonate tautomerase (4OT)

4-Oxalocrotonate decarboxylase (4OD)

2-Oxopent-4-enoate hydratase (OPH)

4-Hydroxy-2-oxovalerate aldolase (HOA)

$\begin{array}{ll}\text { TOL } & \text { NAH } \\ x y l E & n a h H \\ x y l F & n a h N \\ x y l G & n a h I \\ x y l H & n a h J \\ x y l I & n a h K \\ x y l J & \text { nahL } \\ x y l K & \text { nahM }\end{array}$

Table 4. Specific activities of cloned meta pathway enzymes in E. coli and P. putida

Specific activity [milliunits (mg protein $\left.)^{-1}\right] \dagger$

\begin{tabular}{|c|c|c|c|c|c|c|c|c|c|}
\hline & & & & & & & & & \\
\hline Plasmid & Host ${ }^{*}$ & Inducer & $\mathrm{C} 230$ & HMSD & HMSH & $4 \mathrm{OT}$ & $4 O D$ & $\mathrm{OPH}$ & HOA \\
\hline pWW60-1 & P. putida & $\begin{array}{l}\text { None } \\
\text { Salicylate }\end{array}$ & $\begin{array}{l}3 \\
4\end{array}$ & $\begin{array}{l}3 \\
2\end{array}$ & $\begin{array}{l}<0.1 \\
<0.1\end{array}$ & $\begin{array}{l}640 \\
500\end{array}$ & $\begin{array}{r}14 \\
7\end{array}$ & $\begin{array}{l}400 \\
350\end{array}$ & $\begin{array}{l}1 \cdot 3 \\
3 \cdot 8\end{array}$ \\
\hline pWW60-22 & P. putida & $\begin{array}{l}\text { None } \\
\text { Salicylate }\end{array}$ & $\begin{array}{r}14 \\
330\end{array}$ & $\begin{array}{r}3 \\
140\end{array}$ & $\begin{array}{l}0.5 \\
1.2\end{array}$ & $\begin{array}{r}6000 \\
260000\end{array}$ & $\begin{array}{r}33 \\
730\end{array}$ & $\begin{array}{r}980 \\
12000\end{array}$ & $\begin{array}{l}0.9 \\
4.7\end{array}$ \\
\hline pWW60-3037 & $\begin{array}{l}\text { E. coli } \\
\text { P. putida }\end{array}$ & $\begin{array}{l}\text { None } \\
\text { None } \\
\text { Salicylate }\end{array}$ & $\begin{array}{r}74 \\
61 \\
570\end{array}$ & $\begin{array}{r}22 \\
24 \\
390\end{array}$ & $\begin{array}{l}0.5 \\
0.5 \\
4.8\end{array}$ & $\begin{array}{r}34000 \\
71000 \\
880000\end{array}$ & $\begin{array}{r}130 \\
300 \\
2300\end{array}$ & $\begin{array}{r}990 \\
2400 \\
23000\end{array}$ & $\begin{array}{c}\mathrm{ND} \\
3 \cdot 0 \\
66 \cdot 0\end{array}$ \\
\hline pWW60-3026 & $\begin{array}{l}\text { E. coli } \\
\text { P. putida }\end{array}$ & $\begin{array}{l}\text { None } \\
\text { None } \\
\text { Salicylate }\end{array}$ & $\begin{array}{r}71 \\
71 \\
670\end{array}$ & $\begin{array}{r}12 \\
31 \\
550\end{array}$ & $\begin{array}{c}<0.1 \\
1.9 \\
14\end{array}$ & $\begin{array}{r}33000 \\
100000 \\
720000\end{array}$ & $\begin{array}{r}140 \\
420 \\
2900\end{array}$ & $\begin{array}{r}1100 \\
3000 \\
30000\end{array}$ & $\begin{array}{r}\text { ND } \\
5 \cdot 6 \\
57 \cdot 0\end{array}$ \\
\hline pWW60-3046 & $\begin{array}{l}\text { E. coli } \\
\text { P. putida }\end{array}$ & $\begin{array}{l}\text { None } \\
\text { None } \\
\text { Salicylate }\end{array}$ & $\begin{array}{r}110 \\
61 \\
610\end{array}$ & $\begin{array}{r}19 \\
32 \\
490\end{array}$ & $\begin{array}{l}1.2 \\
0.5 \\
5.6\end{array}$ & $\begin{array}{r}36000 \\
62000 \\
950000\end{array}$ & $\begin{array}{r}180 \\
580 \\
5500\end{array}$ & $\begin{array}{r}860 \\
3200 \\
26000\end{array}$ & $\begin{array}{c}\text { ND } \\
1 \cdot 1 \\
16 \cdot 0\end{array}$ \\
\hline pWW60-3032 & $\begin{array}{l}\text { E. coli } \\
\text { P. putida }\end{array}$ & $\begin{array}{l}\text { None } \\
\text { None } \\
\text { Anthranilate }\end{array}$ & $\begin{array}{r}47 \\
20 \\
271\end{array}$ & $\begin{array}{l}<0 \cdot 1 \\
<0 \cdot 1 \\
<0.1\end{array}$ & $\begin{array}{l}<0 \cdot 1 \\
\text { ND } \\
\text { ND }\end{array}$ & $\begin{array}{l}\text { ND } \\
\text { ND } \\
\text { ND }\end{array}$ & $\begin{array}{l}\text { ND } \\
\text { ND } \\
\text { ND }\end{array}$ & $\begin{array}{l}\text { ND } \\
\text { ND } \\
\text { ND }\end{array}$ & $\begin{array}{l}\text { ND } \\
\text { ND } \\
\text { ND }\end{array}$ \\
\hline pWW60-3031 & $\begin{array}{l}\text { E. coli } \\
\text { P. putida }\end{array}$ & $\begin{array}{l}\text { None } \\
\text { None } \\
\text { Anthranilate }\end{array}$ & $\begin{array}{r}330 \\
20 \\
12\end{array}$ & $\begin{array}{l}59 \\
13 \\
20\end{array}$ & $\begin{array}{l}<0.1 \\
<0.1 \\
<0.1\end{array}$ & $\begin{array}{l}\text { ND } \\
\text { ND } \\
\text { ND }\end{array}$ & $\begin{array}{l}\mathrm{ND} \\
\mathrm{ND} \\
\mathrm{ND}\end{array}$ & $\begin{array}{l}\text { ND } \\
\text { ND } \\
\text { ND }\end{array}$ & $\begin{array}{l}\text { ND } \\
\text { ND } \\
\text { ND }\end{array}$ \\
\hline pWW60-3030 & E. coli & None & 1 & $<0.1$ & $<0.1$ & ND & ND & ND & ND \\
\hline pWW60-3027 & $\begin{array}{l}\text { E. coli } \\
\text { P. putida }\end{array}$ & $\begin{array}{l}\text { None } \\
\text { None } \\
\text { Salicylate }\end{array}$ & $\begin{array}{l}<0 \cdot 1 \\
<0 \cdot 1 \\
<0 \cdot 1\end{array}$ & $\begin{array}{l}9 \\
8 \\
8\end{array}$ & $\begin{array}{l}0.5 \\
1 \cdot 0 \\
1 \cdot 1\end{array}$ & $\begin{array}{r}16000 \\
13000 \\
8000\end{array}$ & $\begin{array}{r}75 \\
250 \\
90\end{array}$ & $\begin{array}{l}710 \\
620 \\
630\end{array}$ & $\begin{array}{c}\text { ND } \\
1.4 \\
0.8\end{array}$ \\
\hline pWW60-3038 & E. coli & None & $<0.1$ & $<0 \cdot 1$ & $<0 \cdot 1$ & $<100$ & $<5$ & $<50$ & ND \\
\hline pWW60-3043 & E. coli & None & $<0.1$ & $<0.1$ & $<0.1$ & 6000 & 34 & ND & ND \\
\hline pWW60-3041 & $\begin{array}{l}\text { E. coli } \\
\text { P. putida }\end{array}$ & $\begin{array}{l}\text { None } \\
\text { None }\end{array}$ & $\begin{array}{l}<0 \cdot 1 \\
\text { ND }\end{array}$ & $\begin{array}{l}<0 \cdot 1 \\
\text { ND }\end{array}$ & $\begin{array}{l}\text { ND } \\
\text { ND }\end{array}$ & $\begin{array}{r}27000 \\
6000\end{array}$ & $\begin{array}{l}<5 \\
<5\end{array}$ & $\begin{array}{l}<50 \\
\mathrm{ND}\end{array}$ & $\begin{array}{l}\text { ND } \\
\text { ND }\end{array}$ \\
\hline pWW60-3049 & E. coli & None & 140 & $<0.1$ & ND & ND & ND & ND & ND \\
\hline pWW60-3050 & E. coli & None & $<0.1$ & $<0 \cdot 1$ & $5 \cdot 1$ & ND & ND & ND & ND \\
\hline $\mathrm{pWW60-3051}$ & E. coli & None & $<0.1$ & $<0.1$ & $<0 \cdot 1$ & ND & ND & ND & ND \\
\hline pWW60-3052 & E. coli & None & ND & ND & ND & $<100$ & $<5$ & $<50$ & ND \\
\hline pWW60-3053 & E. coli & None & ND & ND & ND & $<100$ & $<5$ & $<50$ & ND \\
\hline pWW60-3042 & $\begin{array}{l}\text { E. coli } \\
\text { P. putida }\end{array}$ & $\begin{array}{l}\text { None } \\
\text { None }\end{array}$ & $\begin{array}{l}\text { ND } \\
\text { ND }\end{array}$ & $\begin{array}{l}\text { ND } \\
\text { ND }\end{array}$ & $\begin{array}{l}\text { ND } \\
\text { ND }\end{array}$ & $\begin{array}{r}120000 \\
4900\end{array}$ & $\begin{array}{r}11 \\
<5\end{array}$ & $\begin{array}{l}\text { ND } \\
\text { ND }\end{array}$ & $\begin{array}{l}\text { ND } \\
\text { ND }\end{array}$ \\
\hline pWW60-3040 & $\begin{array}{l}\text { E. coli } \\
\text { P. putida }\end{array}$ & $\begin{array}{l}\text { None } \\
\text { None }\end{array}$ & $\begin{array}{l}\text { ND } \\
\text { ND }\end{array}$ & $\begin{array}{l}\text { ND } \\
\text { ND }\end{array}$ & $\begin{array}{l}\text { ND } \\
\text { ND }\end{array}$ & $\begin{array}{r}160000 \\
2600\end{array}$ & $\begin{array}{r}6 \\
<5\end{array}$ & $\begin{array}{l}\text { ND } \\
\text { ND }\end{array}$ & $\begin{array}{l}\mathrm{ND} \\
\mathrm{ND}\end{array}$ \\
\hline None & E. coli & None & $<0 \cdot 1$ & $<0.1$ & $<0.1$ & $<100$ & $<5$ & $<50$ & ND \\
\hline None & P. putida & None & $<0 \cdot 1$ & $<0 \cdot 1$ & $<0.1$ & $<100$ & $<5$ & $<50$ & 1.0 \\
\hline
\end{tabular}

ND, Not determined.

* E. coli ED8654 or JM103 (for pWW60-3050 and pWW60-3051 only) and P. putida PaW130.

$\dagger$ All values represent the mean of three replicates. 
were too low in both hosts for such comparisons to be valid, whereas HOA (nahM) cannot be measured in $E$. coli because of its high NADH oxidase activity.

The genes for $\mathrm{SH}(n a h G)$ and $\mathrm{C} 23 \mathrm{O}(n a h H)$ were located by Cane \& Williams (1986) as shown on Fig. 1. Evidence for the location of the remaining genes was obtained by assaying appropriate subclones of $\mathrm{BC}^{\prime \prime}$.

The product of nahI, HMSD, was detected in strains carrying pWW60-3027 but not pWW603043 , implying that the $X h o I$ site at co-ordinate 9.0 is within the gene. However, nahI must extend only a small distance upstream since the $\mathrm{XhoI}$ fragment $\mathrm{XC}^{\prime \prime}$ showed no hybridization to the upstream end of the isofunctional and homologous gene $x y l G$ from pWW53-4 (probe 2; Fig. 2). Strains carrying pWW60-3041 and pWW60-3049 failed to express nahI but high HMSD

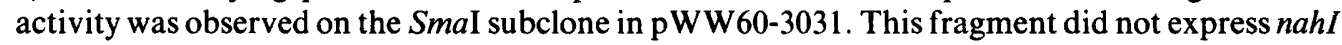

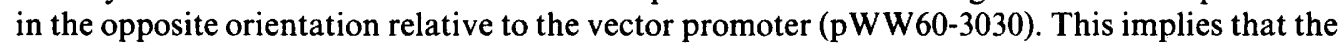
gene terminates between the PvuII site at 10.4 and the SmaI site at $11 \cdot 1$.

The product of $n a h N, \mathrm{HMSH}$, was detected only at very low levels in strains carrying plasmids pWW60-3027 and pWW60-3046. However, when the Sall fragment of BC" between co-

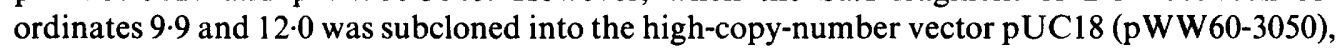
higher HMSH levels were recorded, showing $n a h N$ to be located within this region of BC". With respect to nahJ, 4OT activity was detected in strains carrying pWW60-3027 and four of its subclones, pWW60-3040, pWW60-3041, pWW60-3042 and pWW60-3043. This localizes the gene to between the SmaI site at co-ordinate 14.5 and the HindIII site at $16 \cdot 2$.

It was not possible to localize the remaining three enzyme activities to specific small subclones. The gene products of $n a h K(4 \mathrm{OD})$ and $n a h L(\mathrm{OPH})$ were detected in strains carrying pWW60-3027 but were surprisingly both absent from pWW60-3041. Fine gene localization was not attempted for nahM since the enzyme levels were only measurable under conditions of salicylate induction. The only credible position for the genes is between nahN and nahJ, although their relative order cannot be ascertained from the evidence to date.

\section{Regulation of the meta pathway genes}

Growth in the presence of salicylate of $P$. putida carrying fragment $\mathrm{BC}^{\prime \prime}$ in either orientation (pWW60-3037 or pWW60-3026) resulted in an elevation of specific activities for all enzymes of approximately 10-fold. For pWW60-22 higher levels of induction were observed, ranging from 20 -fold for $\mathrm{C} 23 \mathrm{O}$ and $4 \mathrm{OD}$ to 40 -fold for $4 \mathrm{OT}$ and HMSD. Cells carrying the parent plasmid pWW60-1 exhibited low basal levels of expression for all enzymes and these were not affected by the presence of salicylate.

Cells carrying pWW60-3046, which lacks the upstream $4.2 \mathrm{kbp}$ of $B C^{\prime \prime}$, exhibited similar levels of induction to those carrying $\mathrm{pWW60-3037.} \mathrm{This} \mathrm{implies} \mathrm{that} \mathrm{any} \mathrm{regulatory} \mathrm{element(s)}$ lies downstream of the XhoI site at co-ordinate 4.2. P. putida strains lacking the full meta pathway operon (e.g. pWW60-3031) grew poorly in the presence of salicylate, possibly due to the accumulation of toxic intermediates. With such strains, $5 \mathrm{~mm}$-anthranilate was used as the inducing molecule since this has been shown to be a gratuitous inducer of the meta pathway (Shamsuzzaman \& Barnsley, 1974). Cells carrying pWW60-3032 demonstrated a 10-fold increase in C23O activity in the presence of anthranilate, whereas with pWW60-3031 the level was unaffected by the presence of inducer. This suggests that a regulatory locus (designated $n a h R$ ) lies between the $X h o I$ site at co-ordinate $4 \cdot 2$ and the upstream end of the SH gene.

\section{DISCUSSION}

The 17.5 kbp BamHI fragment BC" from the naphthalene plasmid pWW60-22 was cloned in $E$. coli in the broad-host-range vector pKT230. This fragment was shown to contain all the genetic information required for the metabolism of salicylate via the meta cleavage of catechol. Comparison of the restriction map of $\mathrm{BC}^{\prime \prime}$ of $\mathrm{pWW} 60-22$ with that of TOL plasmid $\mathrm{pWW} 53-4$ HindIII fragment $\mathrm{HA}$ reveals some degree of similarity in the location of restriction sites, notably the XhoI, PstI, Sst I and SmaI sites at co-ordinates 9.0,11.2, 11.6 and 14.6 of BC" 
respectively (Fig. 2). Both operons also display a relative abundance of sites for endonuclease SalI, suggesting a general similarity in base-pair composition and/or codon usage. Comparison of the restriction map of $\mathrm{BC}^{\prime \prime}$ with that of the meta pathway operon of naphthalene plasmid NAH7 reveals a greater degree of restriction site conservation (Harayama et al., 1987b), possibly indicative of a more recent evolutionary link.

DNA hybridization has been used previously to demonstrate homology between the meta cleavage pathway genes of NAH and TOL plasmids (Bayley et al., 1979; Farrell \& Chakrabarty, 1979; Lehrbach et al., 1983; Cane \& Williams, 1986). The present study aimed to elucidate the exact nature and extent of these structural similarities by employing a sequential series of specific DNA hybridization probes. A strong degree of DNA homology was observed, commencing at the $\mathrm{C} 23 \mathrm{O}$ gene and extending along the full length of the NAH and TOL structural genes. The pattern of hybridization using DNA probes designed to hybridize only to small regions of specific genes was highly indicative of the same gene order on the two operons.

The demonstration of homology between the $1.6 \mathrm{kbp}$ of DNA deleted in pWW60-1 to yield pWW60-22, and the region of pWW53-4 immediately preceding $x y l D$ at the upstream end of the meta pathway operon, is further evidence for a relationship between the two operons and suggests an attractive hypothesis for the evolutionary history of the meta cleavage pathway. It is possible that the naphthalene catabolic pathway was formed by the chance combination on a single replicon of three pre-evolved metabolic 'modules', one controlling the breakdown of naphthalene to salicylate, a second encoding SH under the regulatory control of nahR and a third element responsible for the meta pathway enzymes. This latter unit is presumed to share a common origin with the TOL meta pathway operon and may originally have included functional genes for $x y l D$ and $x y l L$ and an independent operator-promoter region. Selective pressure for the retention of $x y l D L$ would be minimal due to the existence of isofunctional chromosomal genes, thus allowing the accumulation of non-deleterious point mutations and deletions within this region. The eventual deletion of the vestigial DNA between the SH and C23O genes in pWW60-1 would then form a single operon under the regulatory control of nahR. This is the case on NAH7, where the order of the meta pathway genes is identical to pWW60-22 with the exception of $n a h J$ and $n a h K$, whose relative order is reversed. An evolutionary relationship has also been proposed between NAH7 and the archetypal TOL plasmid pWW0 on the basis of similarities in the nucleotide and amino acid sequences of their $\mathrm{C} 23 \mathrm{O}$ genes (Harayama et al., $1987 b)$.

Assaying strains carrying $\mathrm{BC}^{\prime \prime}$ and its subclones for enzyme activities allowed the location of the majority of the genes to small regions of DNA which corresponded to the positions indicated by hybridization with gene-specific probes. Although their activities could be assayed on BC", it was not possible to locate the genes for $n a h K$ or $L$ to specific small subclones. It is conceivable that the restriction sites available for cloning in pKT230 lie within the genes, but this seems unlikely to account for the lack of nahK activity in pWW60-3041. The analogous gene on TOL plasmid pWW0 $(x y l)$ has been shown to lie immediately upstream of $x y l H$ encoding 4OT. A subclone of the pWW53-4 meta pathway operon derived from this region hybridized to the equivalent position on BC' $^{\prime \prime}$ (probe 5; Fig. 2) but we have been unable to confirm experimentally the previous report (Keil et al., 1987) that this subclone expresses 4OD activity. Hence, its hybridization does not necessarily imply the presence of $n a h K$ in this position although it is consistent with a co-linearity of gene order. It is possible that the arrangement of $n a h K$ and $n a h L$ may be more complicated than has previously been envisaged, perhaps involving more than one gene coding for each enzyme. It is clear that further work is needed in this respect, both on the NAH operon and on the TOL meta pathway where the full complexities of the system may not yet have been recognized.

The specific activities of HMSH in strains carrying pWW60-22 and its subclones were low, although a functional $n a h N$ gene was localized by subcloning an appropriate fragment into a high-copy-number vector (pWW60-3050). This is consistent with the observation that the hydrolytic branch of the pathway is of no metabolic significance in strain NCIB 9816 (Catterall et al., 1971). It has been shown for TOL plasmid pWW0 that only 3-methylcatechol is dissimilated via the hydrolytic branch and that catechol and 4-methylcatechol are catabolized 
almost exclusively by the 4-oxalocrotonate pathway (Murray et al., 1972; Wigmore et al., 1974; Harayama et al., 1987a). The low activity of HMSH in pWW60-22 may thus have evolved as a consequence of a limited availability of 1-methylnaphthalene as a naturally-occurring substrate compared to naphthalene and 2-methylnaphthalene.

The existence of a regulatory gene $n a h R$ was clearly demonstrated by the induction of enzyme activities in the presence of salicylate. The nahR locus was shown to lie immediately upstream of the $n a h G$ gene in an identical position to the analogous gene on NAH7 (Yen \& Gunsalus, 1985). The levels of induction of cloned genes were generally approximately two- to fourfold lower than observed for the native plasmid pWW60-22 in a $P$. putida host. However, it is likely that the nature of the cloning vehicle and, particularly, its copy number may have a major effect on the level of expression and this result does not necessarily imply that additional regulatory elements exist elsewhere in the plasmid. There certainly do not appear to be regulatory genes homologous to $x y l R$ and $x y l S$ of $\mathrm{pWW} 53-4$. Specific DNA probes for these genes failed to hybridize and the downstream end of $\mathrm{BC}^{\prime \prime}$ does not exhibit the two highly conserved restriction sites for BgIII which are characteristic of the $x y l S R$ regulatory region (Keil et al., 1987). This suggests that the regulatory control of certain metabolic pathways may evolve subsequent to the development of their catalytic functions.

The concept that a structurally heterogeneous group of catabolic plasmids may share a common evolutionary origin is becoming increasingly substantiated by fact. The present study provides strong evidence for an evolutionary relationship between TOL plasmid pWW53-4 and the naphthalene plasmid pWW60-22. Hybridization evidence has been complemented with enzyme assay data to show that the two meta pathway operons are related at the DNA level and identical in their structural gene organization. This paper thus adds to an accumulating body of data which should ultimately yield important information regarding the evolution of peripheral catabolic pathways.

We would like to thank Mrs L. Shaw for technical assistance. This work was funded by SERC grant no. GR/D17557.

\section{REFERENCES}

Bagdasarian, M., Lurz, R., Rückert, B., Franklin, F. C. H., Bagdasarian, M. M., Frey, J. \& Timmis, K. N. (1981). Specific-purpose cloning vectors. II. Broad host range, high copy number RSF1010derived vectors and a host: vector system for gene cloning. Gene 16, 237-247.

Bagdasarian, M. M., Amann, E., Lurz, R., RückERT, B. \& Bagdasarian, M. (1983). Activity of the hybrid trp-lac (tac) promoter of Escherichia coli in Pseudomonas putida. Construction of broad host range, regulatable expression vectors. Gene $26,273-$ 282.

Bayley, S. A., Morris, D. W. \& Broda, P. (1979). The relationship of degradative and resistance plasmids of Pseudomonas belonging to the same incompatibility group. Nature, London 280, 338-339.

Bolivar, F., Rodriguez, R. L., Green, P. J., Betlach, H. C., Heynecker, H. L., BOyer, H. W., Crosa, J. J. \& FALKOW, S. (1977). Construction and characterisation of new cloning vehicles. II. A multipurpose cloning system. Gene 2, 95-113.

Boronin, A. M., Kochetov, V. V., StaRovortov, I. I. \& SkRYABIN, G. K. (1977). Plasmids pBS2 and pBS3, controlling the oxidation of naphthalene in bacteria of the genus Pseudomonas. Doklady Academii nauk SSSR 237, 1205-1208.

Boronin, A. M., Kochetov, V. V. \& Skryabin, G. K. (1980). Incompatibility groups of naphthalene degradative plasmids in Pseudomonas. FEMS Microbiology Letters 7, 249-252.

Cane, P. A. \& Williams, P. A. (1982). The plasmidcoded metabolism of naphthalene and 2-methylnaphthalene in Pseudomonas strains: phenotypic changes correlated with structural modification of the plasmid pWW60-1. Journal of General Microbiology 128, 2281-2290.

Cane, P. A. \& Williams, P. A. (1986). A restriction map of naphthalene catabolic plasmid pWW60-1 and the location of some of its catabolic genes. Journal of General Microbiology 132, 2919-2929.

Catterall, F. A., Sala-Trepat, J. M. \& Williams, P. A. (1971). The coexistence of two pathways for the metabolism of 2-hydroxymuconic semialdehyde in a naphthalene-grown pseudomonad. Biochemical and Biophysical Research Communications 43, 463-469.

Cohen, S. N., Chang, A. C. Y. \& Hsu, C. L. (1972). Non-chromosomal antibiotic resistance in bacteria: genetic transformation of Escherichia coli by $\mathbf{R}$ factor DNA. Proceedings of the National Academy of Sciences of the United States of America 69, 21102114.

Collinsworth, W. L., Chapman, P. J. \& Dagley, S. (1973). Stereospecific enzymes in the degradation of aromatic compounds by Pseudomonas putida. Journal of Bacteriology 113, 922-931.

Dunn, N. W. \& Gunsalus, I. C. (1973). Transmissible plasmid coding early enzymes of naphthalene oxidation in Pseudomonas putida. Journal of Bacteriology 114, 974-979.

Farrell, R. \& Chakrabarty, A. M. (1979). Degrada- 
tive plasmids: molecular nature and mode of evolution. In Plasmids of Medical, Environmental and Commercial Importance, pp. 97-109. Edited by K. N. Timmis \& A. Puhler. Amsterdam: Elșevier/North Holland Biomedical.

Feist, C. F. \& Hegeman, G. D. (1969). Phenol and benzoate metabolism by Pseudomonas putida: regulation of tangential pathways. Journal of Bacteriology 100, 869-877.

Franklin, F. C. H., Bagdasarian, M., Bagdasarian, M. M. \& Timmis, K. N. (1981). Molecular and functional analysis of the TOL plasmid pWW0 from Pseudomonas putida and cloning of genes for the entire regulated aromatic ring meta cleavage pathway. Proceedings of the National Academy of Sciences of the United States of America 78, 7458-7462.

Girvitz, S. C., Bacchetti, S., Rainbow, A. J. \& Graham, F. W. (1980). A rapid and efficient procedure for the purification of DNA from agarose gels. Analytical Biochemistry 106, 492-496.

GrINTER, N. J. (1983). A broad-host range cloning vector transposable to various replicons. Gene 21, 133-143.

Guerry, P., Leblanc, D. J. \& Falkow, S. (1973). General method for the isolation of plasmid deoxyribonucleic acid. Journal of Bacteriology 116, 1064-1066.

Harayama, S., Lehrbach, P. R. \& Timmis, K. N. (1984). Transposon mutagenesis of meta-cleavage pathway operon genes of the TOL plasmid of Pseudomonas putida mt-2. Journal of Bacteriology 160, 251-255.

Harayama, S., Mermod, N., Rekik, M., Lehrbach, P. R. \& Timmis, K. N. $(1987 a)$. Roles of the divergent branches of the meta-cleavage pathway in the degradation of benzoate and substituted benzoates. Journal of Bacteriology 169, 558-564.

Harayama, S., Rekik, M., Wasserfallen, A. \& BAIROCH, A. $(1987 b)$. Evolutionary relationships between catabolic pathways for aromatics: conservation of gene order and nucleotide sequences of catechol oxidation genes of pWW0 and NAH7 plasmids. Molecular and General Genetics 210, 241247.

Holmes, D. S. \& Quigley, N. (1981). A rapid boiling method for preparation of bacterial plasmids. Analytical Biochemistry 114, 193-197.

KeIL, H. \& Williams, P. A. (1985). A new class of TOL plasmid deletion mutants in Pseudomonas putida MT15 and their reversion by tandem gene amplification. Journal of General Microbiology 131, 1023-1033.

KeIL, H., Lebens, M. R. \& Williams, P. A. (1985a). TOL plasmid pWW15 contains two non-homologous catechol 2,3-oxygenase genes independently regulated. Journal of Bacteriology 163, 248-255.

KeIl, H., KeIL, S., PickuP, R. W. \& Williams, P. A. $(1985 b)$. The complete meta pathway operon of the toluene/xylene catabolic pathway cloned from TOL plasmid pWW53. Journal of Bacteriology 164, 887895.
Keil, H., Keil, S. \& Williams, P. A. (1987). Molecular analysis of regulatory and structural $x y l$ genes of the TOL plasmid pWW53-4. Journal of General Microbiology 133, 1149-1158.

LehrbaCh, P. R., MCGregor, I., Ward, J. M. \& BRODA, P. (1983). Molecular relationships between Pseudomonas IncP-9 degradative plasmids TOL, NAH and SAL. Plasmid 10, 164-174.

Messing, J., Crea, R. \& Seeburg, P. H. (1981). A system for shotgun DNA sequencing. Nucleic Acids Research 9, 309-321.

Murray, K., Duggleby, C. J., Sala-Trepat, J. M. \& Williams, P. A. (1972). The metabolism of benzoate and methylbenzoates via the meta-cleavag 2 pathway by Pseudomonas arvilla mt-2. European Journal of Biochemistry 28, 301-310.

Murray, N. E., Brammar, W. J. \& Murray, K. (1977). Lambdoid phages that simplify the recovery of in vitro recombinants. Molecular and General Genetics 150, 53-61.

Sala-Trepat, J. M. \& Evans, W. C. (1971). The meta cleavage of catechol by Azotobacter species: 4oxalocrotonate pathway. European Journal of Biochemistry 20, 400-413.

Schell, M. A. \& Wender, P. E. (1986). Identification of the nahR gene product and nucleotide sequences required for its activation of the sal operon. Journal of Bacteriology 166, 9-14.

Shamsuzzaman, K. M. \& Barnsley, E. A. (1974). The regulation of naphthalene oxygenase in pseudomonads. Journal of General Microbiology 83, 165-170.

SOUTHERN, E. M. (1975). Detection of specific sequences among DNA fragments separated by gel electrophoresis. Journal of Molecular Biology 98, 503-571.

SPOONER, R. A., LindSAY, K. \& FRANKLIN, F. C. H. (1986). Genetic, functional and sequence analysis of the $x y l R$ and $x y l S$ regulatory genes of the TOL plasmid pWW0. Journal of General Microbiology 132, 1347-1358.

WhęATCRoft, R. \& Williams, P. A. (1981). Rapid methods for the study of both stable and unstable plasmids in Pseudomonas. Journal of General Microbiology 124, 433-437.

Wigmore, G. J., BAyly, R. C. \& Di Berardino, D. (1974). Pseudomonas putida mutants defective in the metabolism of the products of meta fission of catechol and its methyl analogs. Journal of Bacteriology 120, 31-37.

WORSEY, M. J. \& Williams, P. A. (1975). Metabolism of toluene and xylenes by Pseudomonas putida (arvilla) $\mathrm{mt}-2$ : evidence for a new function of the TOL plasmid. Journal of Bacteriology 124, 7-13.

Yanisch-Perron, C., Vieira, J. \& MESSING, J. (1985). Improved M13 phage cloning vectors and host strains: nucleotide sequences of the $\mathrm{M} 13 \mathrm{mpl} 18$ and pUC19 vectors. Gene 33, 103-119.

YEN, M. \& GunsaluS, I. C. (1985). Regulation of naphthalene catabolic genes of plasmid NAH7. Journal of Bacteriology 162, 1008-1013. 